\title{
What Explains the Low Success Rate of Investor-State Disputes?
}

\author{
Krzysztof J. Pelc
}

\begin{abstract}
The treatment of foreign investment has become the most controversial issue in global governance. At the center of the controversy lies the mechanism of investor-state dispute settlement (ISDS), which allows private firms legal recourse against governments if government interference has degraded their investment. Using newly released data covering 742 investment disputes, I assess some of the central claims about ISDS. I argue that the regime has indeed undergone an important shift: a majority of claims today deal not with direct takings by low-rule-of-law countries, but with regulation in democratic states. Such "indirect expropriation" claims have seen a precipitous decrease in their odds of legal success over the past twenty years. They are also far less likely to result in early settlement. These parallel trends may be a result of a rise in strategic litigation by investors whose aim is not only to obtain compensation but also to deter governments' regulatory ambitions.
\end{abstract}

The treatment of foreign investment has unexpectedly become the most controversial issue in global governance. Currently, two major transatlantic trade agreements are in jeopardy over their investment provisions. ${ }^{1}$ At the center of this controversy lies the mechanism of investor-state dispute settlement (ISDS), which allows private companies to bring legal claims against a host government. If the government's actions are found to have degraded the company's investment in breach of an investment treaty, the company can be awarded financial compensation. The mechanism of ISDS is far from new: it emerged during the postcolonial era as a way of protecting Western investors from expropriation and nationalization by governments in countries with weak rule of law. But only in recent years has it generated this level of contention.

In response, policy-makers frequently point out that investors lose most of the claims they bring, and that ISDS thus poses little true threat to legitimate government measures. ${ }^{2}$ This leads to an overlooked puzzle: why would investors continue to file these costly cases if the expected success rate is so low? The puzzle is only sharpened when one takes a closer look at the data. Current estimates actually overstate investors' success rates, especially when it comes to specific types of legal claims. What is

I thank Vincent Arel-Bundock, Eric Arias, Leonardo Baccini, Matthew Castle, Mark Kantor, Armand de Mestral, Joost Pauwelyn, Peter Rosendorff, and the participants of seminars at McGill and NYU, as well as the OGEMID group for most helpful comments. Lauren Konken and Sean Nossek provided valuable research assistance. All remaining errors my own.

1. See the Canada-EU CETA agreement and the US-EU TTIP agreement. In both cases, the investment chapter constitutes the agreement's greatest point of contention.

2. European Commission 2013. 
more, this rate of success has been dropping precipitously - the opposite of what we might expect of a maturing legal system in which expectations over what constitutes a violation converge over time.

Using newly released data, I distinguish the 1,812 individual legal claims brought across 742 investment disputes, from 1993 to the present day. These data allow me to show how the investment regime has shifted in its primary purpose since its origins. Most disputes today are not over "sovereign theft" or direct takings, but over indirect expropriation. And most respondent countries are not rent-seeking regimes with low rule of law, but stable democracies with independent judiciaries. To put it in stark terms, the greatest portion of legal challenges in the investment regime today seeks monetary compensation for regulatory measures implemented by democracies.

Indirect expropriation differs in a number of ways from direct expropriation, starting with the fact that the state usually derives no revenue from its alleged expropriatory act. Even when governments eventually win a case, investor-state litigation is extremely costly: not only are the legal costs many times higher than in, for example, trade disputes, but aggregate investment flows appear to suffer from litigation, no matter its outcome. ${ }^{3}$ As a result, governments are especially eager to avoid litigation. Knowing this, firms may have an incentive to use litigation strategically to temper governments' regulatory ambitions. When Philip Morris challenged Australia's tobacco-labeling regulations, New Zealand put its own labeling legislation on hold, and Philip Morris loudly praised the decision. ${ }^{4}$ If litigation exerts a sufficient deterrent effect, firms may benefit even when they lose a case. I argue that this side-benefit, if it exists, should skew the average legal merit of cases downwards, in a way that should affect success rates at the ruling stage.

Studies of legal outcomes invariably come up against the twin challenge of observability and selection: one can observe only those cases that are formally filed. Without knowing what policies were prone to challenge in the first place, any analysis risks selection bias. While it is an often-insurmountable issue, here I seek to use selection to my advantage, by formulating expectations over the outcome of those cases that one does observe, given that one knows selection is occurring. Specifically, if investors are rationally selecting cases, and indirect expropriation claims are more likely to carry positive spillover effects from their standpoint, then one expects investors to require a lower level of legal merit to file a case, all else equal. As a result, those indirect expropriation claims that are filed should fare less well in litigation. Second, if the goal is not limited to resolving the underlying dispute, but also in part to deter regulation, then indirect expropriation claims should be associated with lower rates of early settlement, and they should be more likely to drag out until a ruling is rendered.

3. Allee and Peinhardt 2011.

4. Philip Morris International 2013. 
Findings looking at investment disputes from 1993 to 2015 offer support for these beliefs. While the "explosion" of investment disputes has been widely recognized, ${ }^{5}$ the legal success of these disputes has steadily dropped over time. This trend is especially apparent when it comes to indirect expropriation. The record of investment disputes is consistent with the view that the regime is increasingly being used to challenge domestic regulation. One unintended effect we are seeing is an increase in low-merit claims over time. Firms are litigating more and more, and they are winning less and less: to wit, investors succeed in less than 10 percent of the indirect expropriation claims they bring against democratic countries.

\section{Ancient Regime, Recent Changes}

That the property of foreign investors cannot be taken by a government without the payment of "prompt, adequate and effective compensation" is well established in customary international law. ${ }^{6}$ In his discussion of property rights, Hugo Grotius had already elaborated a theory of expropriation by the mid-seventeenth century. ${ }^{7}$ The ISDS regime itself is also far from new: its broad outlines were first elaborated in the Draft Convention on Investments Abroad in 1959. Countries have gone on to sign over three thousand bilateral investment treaties, and sixty trade agreements with investment chapters. Given this long history, policy-makers themselves appear taken aback by how the protection of foreign investment has become the object of so much public attention. Cecilia Malmström, the EU Commissioner for trade, recently noted that of all the issues in its trade negotiations with the US, investment, and specifically ISDS, "has received the most attention and raised the most concern." She went on to say that "in some ways that's surprising. Over sixty years, national governments in the EU negotiated 1,400 bilateral investment treaties without any outcry." 8 The lead Canadian negotiator, Steve Verheul, also admitted that opposition to ISDS came as a "significant surprise."

But despite an established history, the exact contours of what constitutes expropriation have never been as hazy. What legal scholars $d o$ agree on is that the concept of expropriation has progressively moved beyond direct takings of property by governments, and gone on to encompass other acts that have effects "equivalent to" such takings. The concept of indirect expropriation is not new, either, but its frequent invocation is: Escarcena aptly describes it as a "dormant issue" in international law. ${ }^{10}$

5. See Simmons 2014; and Allee and Peinhardt 2011.

6. The phrase was drafted by Cordell Hull in the wake of Mexico's nationalization of American oil interests in 1936.

7. Reynolds 2010.

8. Cecilia Malmström, "Opening Remarks: Discussion on Investment in TTIP," Brussels Meeting of the International Trade Committee of the European Parliament, 18 March 2015.

9. Janyce McGregor, "EU Quietly Asks Canada to Rework Trade Deal's Thorny Investment Clause," CBC News, 21 January 2016.

10. Escarcena 2014, 6. 
Expropriation is indirect when it does not involve a transfer of property, but nonetheless deprives the investor of the enjoyment of her property, such as when regulation degrades the value of an investment. But as one of the main arbitrators in the ISDS regime puts it, "international law has yet to draw a bright and easily distinguishable line between regulation and expropriation, especially indirect expropriation."11

The other reason for the sudden increase in public attention is the sheer volume of litigation. While the ISDS regime is nominally over fifty years old, the majority of cases brought over the regime's entire history have been filed in the last decade. For all intents and purposes, states and investors are dealing with a new legal recourse option.

Figure 1 illustrates both these trends. The UNCTAD data set I rely on begins in 1993. But if the timeline were stretched further back in time, litigation activity would be seen to sputter at its minimum level from the early 1970s to 1996, when it suddenly picks up, as Figure 1 indicates. ${ }^{12}$ The chart shows how the volume of both direct and indirect expropriation cases has increased in time. It is not that countries are no longer accused of direct takings. But the increase in indirect expropriation cases has been more pronounced, and the past two decades are dominated by these claims.

Indirect and direct expropriation claims within cases are effectively mutually exclusive. ${ }^{13}$ Since 1993, over 70 percent of all cases have featured an indirect expropriation claim, while only 16 percent have featured a direct expropriation claim. Indirect expropriation is thus the most commonly invoked claim in investment disputes in the last twenty years, alongside claims of fair and equitable treatment, with which it is often packaged. ${ }^{14}$ By comparison, national treatment claims are brought three times less often, and most-favored nation claims are brought four times less often than indirect expropriation claims: the current investment regime is not chiefly concerned with discrimination.

Figure 1 and the analyses that follow are based on recently released data from UNCTAD's Investment Dispute Settlement Navigator. ${ }^{15}$ The goal of this considerable data collection effort is to document all publicly known cases launched under an international investment agreement. It deliberately excludes only disputes that arise out of commercial contracts or domestic investment legislation. Its resulting coverage includes 742 investment disputes. Launched in late 2015, it is the most complete database of investment disputes for the period it covers, and the only one to code

11. Fortier and Drymer 2004, 299.

12. See Schultz and Dupont 2014. These data cover fewer disputes but stretch further back in time.

13. Only 2 percent of all known cases include both claims; a breach under both has never been found in the same case.

14. As Dolzer puts it, the fair and equitable treatment clause is "in its substance closely related to the more specific standards of an indirect expropriation," and is often added to "round out the case" $(2005,87)$.

15. UNCTAD Investment Dispute Settlement Navigator 2016. Available at <http://investmentpolicyhub. unctad.org/ISDS/>, accessed 3 February 2017. 
disputes at the claim level. ${ }^{16}$ In other words, these data come closest to representing the full universe of investment disputes in what remains an otherwise opaque setting.

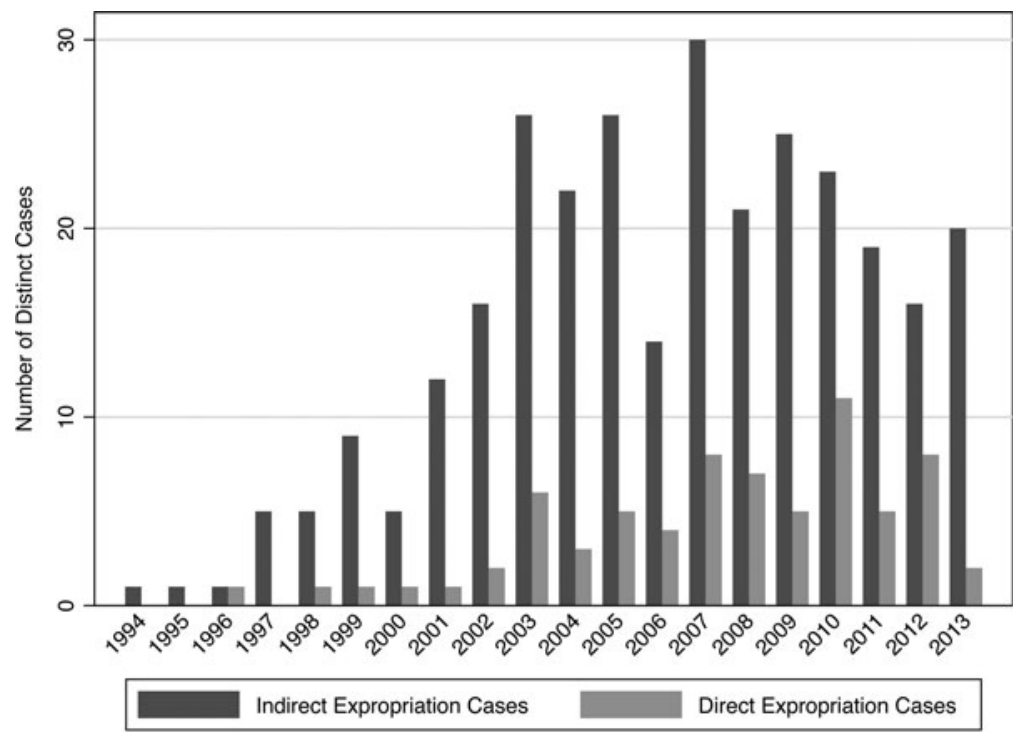

Source: UNCTAD 2016.

FIGURE 1. Direct vs. indirect expropriation claims in ISDS

While the possibility for indirect expropriation was present in earlier agreements, the North American Free Trade Agreement (NAFTA) was instrumental in making it a frequent legal recourse by firms. Its investment section, chapter 11, innovated by covering acts "tantamount to" expropriation. That clause, in turn, drew heavily on US domestic law over regulatory takings, which recognized that "if regulation goes too far it will be recognized as a taking." ${ }^{17}$ Litigation under NAFTA also generated what is likely the most expansive legal interpretation of indirect expropriation, in the Metalclad case from 2000, as including "covert and incidental interference ... even if not necessarily to the obvious benefit of the host state." 18

This last condition, obviating the requirement for some gain on the part of the state, confirmed that the expropriatory effect could be entirely incidental to the regulation at issue. The government need neither intend to expropriate, nor gain from doing so, for a measure to be deemed expropriatory. The Metalclad award is often favorably cited

16. By comparison, a recent empirical analysis by a prominent legal scholar relies on 159 disputes. See Franck 2015.

17. Fortier and Drymer 2004.

18. Metalclad Corporation v. The United Mexican States, ICSID No. ARB(AF)/97/1, paragraph 103 (emphasis added). 
by claimants in indirect expropriation disputes across the investment regime. ${ }^{19}$ Meanwhile, other awards have given more weight to the government's ability to regulate for the public good. Two years after Metalclad, the arbitrators in another dispute against the same country and under the same agreement emphasized that "governments must be free to act in the broader public interest" through regulation, which "cannot be achieved if any business that is adversely affected may seek compensation." 20

In sum, there remains considerable ambiguity about what constitutes indirect expropriation, and what distinguishes it from noncompensable regulation. Yet one thing is plain: this ambiguous provision has become the investment regime's bread and butter. Indirect expropriation provisions are also present in the most recently concluded large deals between states, such as the Trans-Pacific Partnership (TPP). ${ }^{21}$

Beyond its greater legal ambiguity, another aspect of indirect expropriation points to the need for a re-evaluation of current theoretical expectations in the study of investment. Indirect expropriation most often offers the host state no short-term windfall. In the case of direct takings, when governments nationalize foreign assets, or forcibly transfer title, they gain the value of those assets. In fact, for some time, the enrichment of the host state was one test by which a tribunal might recognize whether expropriation had taken place. Not so in the case of indirect expropriation, where an investment's value is most often degraded without it benefiting the host state. When Indonesia banned open-pit mining in protected forests, when Germany decided to phase out nuclear energy by 2022, and when Australia imposed plain packaging on cigarette makers, the state did not derive any direct financial benefit. Conversely, when Venezuela, in 2007, nationalized all oil projects, including profit-sharing projects that had until then been exempted from the prior 2001 Hydrocarbons Law, it gained the entire value of the associated rights over oil exploration and production..$^{22}$ To be sure, rogue governments can use creeping legislative measures in bad faith to purposefully degrade the value of investment-consider Russia's treatment of the energy firm Yukos. ${ }^{23}$ And governments might seek to get out of onerous commitments to firms through regulatory means. But on average, direct expropriation happens because of the presence of an investment, while indirect expropriation happens despite the presence of an investment.

The evolution of case law offers support for this view. The rise of indirect expropriation claims is the very reason cited for the rejection in case law of the requirement that for a measure to be expropriatory it must enrich the host state. ${ }^{24}$ The reasoning behind the change was that to require proof of enrichment would peremptorily

19. See, for example, InterTrade v. Czech Republic, PCA Case No. 2009-12.

20. Feldman v. Mexico, ICSID Case ARB(AF)/99/1, paragraph 103.

21. TPP Investment Chapter, Annex 9-B: 2.

22. See Mobil v. Venezuela, ICSID Case No. ARB/07/27.

23. See Gibson 2015.

24. For an exception, see the ICSID decision in Olguín v. Paraguay, ICSID Case No. ARB/98/5. 
"negate the protection against indirect expropriation" since in most cases, indirect expropriation gives rise to no such benefit. ${ }^{25}$

These distinctions hold important implications for theory. A large literature in international political economy examines the investment regime. Many of these studies rest on a view of the regime as offering protection from "sovereign theft," usually by autocratic regimes. ${ }^{26}$ Yet such measures are no longer representative of expropriation. As I will show, a full 64 percent of investment disputes in the last two decades target democracies, and this proportion has been rising. When scholars examine the circumstances under which expropriation grows most likely, they usually focus on the benefit to government of seizing assets. In this way, Cole and English build a model where expropriation is likely when output prices are high. ${ }^{27}$ Jensen and colleagues view "expropriations as a form of redistribution during crisis" and argue that the temptation to expropriate thus peaks during crises. ${ }^{28}$ Pelc and Urpelainen base their model on the way in which the (monetary) gains from breaches in the investment regime accrue directly to governments, rather than firms, as in the case of the trade regime. ${ }^{29}$ But such expectations no longer comport with the median alleged breach in the investment regime, since indirect expropriation most often does not bring the government any windfall revenue. The type of expropriation that these studies have in mind constitutes only 16 percent of the ISDS regime's entire caseload over the last two decades.

Finally, that there has been a shift, and that this shift was not expected by signatories is supported by the fact that the default remedy in the investment regime is monetary compensation, rather than compliance. As Pauwelyn argues, when dealing with direct expropriation, awarding "damages as standard remedy makes sense," but not "when it comes to treaty claims against public laws or regulations." 30 In domestic legal regimes, regulatory breaches tend to be remedied through "performance." The designers of rules where the standard remedy is monetary compensation would most likely have had in mind challenges over direct takings.

\section{The Incentives of Parties in ISDS}

One defining trait of the ISDS regime is that it allows for private standing: firms or individuals can themselves bring suit against governments. This feature of ISDS is, according to some, consistent with rational design: given that investment represents high sunk costs, governments' credibility problem when it comes to investors is such

25. Fortier and Drymer 2004, 314.

26. See Jensen et al. 2012; Li and Resnick 2003; Tomz and Wright 2010.

27. Cole and English 1991.

28. Jensen et al. 2012, 8 .

29. Pelc and Urpelainen 2015.

30. Pauwelyn 2014, 410. 
that a high level of enforcement is required. ${ }^{31}$ Others describe it instead as a "historical accident": an unplanned, incidental development, the intent of which was to keep commercial disputes from spilling over into interstate relations. ${ }^{32}$

Regardless of its origins, private standing eliminates an important source of restraint against raising legal challenges by doing away with reciprocity and the fear of retaliatory challenges. Legal challenges between sovereign nations come at considerable political cost. ${ }^{33}$ The continued interaction between states in a forum such as the trade regime means that belligerent countries' reputations may suffer. By contrast, investors have less reason to exercise restraint.

Private standing has long been a feature of ISDS and thus it cannot, by itself, explain a recent shift in the volume or nature of litigation. Rather, the point is that as the perceived gains from litigation increase, the design of the investment regime does not have in place the natural barriers preventing an "explosion of cases." 34 Investors launch a case whenever the cost of legal counsel is outweighed by the benefits of litigation.

\section{The Cost of Investment Disputes to Governments}

The argument hinges in large measure on the high cost of ISDS litigation to governments. In a 2010 report, UNCTAD admitted that "contrary to the expectations ... costs involved in investor-State arbitration have skyrocketed in recent years." ${ }^{35}$ There is every indication that these costs have kept increasing. In the case of ICSID, a recent estimate finds average costs per dispute of USD 5.5 million for governments since $2011 .^{36}$ This is about five times more than the average WTO disputethe same ratio by which arbitrators' fees at ICSID outstrip panelist fees at the WTO. ${ }^{37}$ And even in the case of trade disputes, countries often mention scarce legal resources as the reason they avoid challenging offending barriers. ${ }^{38}$ Since both trade and investment litigation come out of the same "pocket," governments should be similarly wary of litigation in investment, where its cost is far higher. In fact, governments have explicitly tied the high cost of defending against low-merit claims with the effect these may have on policy, a concern not limited to poor countries. As the European Union DG for Trade admitted during public consultations on the matter:

31. Simmons 2014.

32. Pauwelyn 2014, 404.

33. Busch, Reinhardt, and Shaffer 2009.

34. Simmons $2014,41$.

35. UNCTAD 2010.

36. Commission 2016 finds that average ICSID costs to governments from FY2011 to FY2015 were $\$ 4,954,461$, and total tribunal costs, which are usually split between parties, were $\$ 882,668$.

37. Pauwelyn 2015, 23.

38. See Johns and Pelc 2016. Brutger 2014 describes wealthy governments relying on private firms to help fund WTO disputes. 
As in all legal systems, cases are brought that have little or no chance of succeeding (so-called "frivolous claims"). Despite eventually being rejected by the tribunals, such cases take up time and money for the responding state. There have been concerns that protracted and frequent litigation in ISDS could have an effect on the policy choices made by states. ${ }^{39}$

From the state's standpoint, the costs of litigation are not limited to legal fees, high though these may be. Allee and Peinhardt show how investment disputes undo much of the benefit of international investment agreements as measured by investment flows. ${ }^{40}$ Crucially, this effect is present even if governments ultimately prevail in the dispute. Because international disputes are costly actions, they are usually thought to be credible indicators of rent-seeking behavior by states. ${ }^{41}$ But if a large proportion of disputes in the investment regime is of low merit, this no longer holds.

Governments thus have an incentive to avoid litigation, even if they believe they will ultimately prevail on the merits. As the EU itself emphasizes, "even if the responding state is successful in defending its measures in front of the ISDS tribunal, it may have to pay substantial amounts to cover its own defence." 42 But this incentive will be highest for developing countries, for whom all such costs are relatively more onerous.

\section{Regulation and the Threat of Litigation}

What explains the low success rate of investment disputes? If rational claimants file a case knowing it is of low legal merit, it may be because litigation itself brings some other benefit. In the case of indirect expropriation, in particular, an additional benefit derived from litigation may be the possibility of tempering governments' regulatory ambitions. Popular accounts have associated indirect expropriation claims with the threat of "regulatory chill," yet the reasoning behind these claims is often murky. Here I seek to assess it more systematically.

Direct takings are idiosyncratic in a way that regulation is not. Direct expropriation occurs in a specific context. Meanwhile, regulation can spread across countries. A large literature on diffusion attests to how countries learn from one another's policies in arriving at their own policy profile. ${ }^{43}$ In the same way, governments may draw conclusions about the desirability of policies by seeing these attacked in highprofile disputes. ${ }^{44}$ Public health and environmental initiatives across different countries increasingly rely on the same scientific standards, as with smoking laws, nuclear

39. DG Trade 2014.

40. Allee and Peinhardt 2011.

41. Mansfield, Milner, and Rosendorff 2002.

42. DG Trade 2014.

43. See, for example, Lazer 2001; Post 2005; and Simmons and Elkins 2004.

44. For analogous deterrence in international trade disputes, see Kucik and Pelc 2016a. 
energy, and fracking regulation, to take recent salient cases. ${ }^{45}$ The result is that while it is conceivable that direct expropriation challenges might carry a deterrent effect-if only by demonstrating willingness to litigate- this is far more likely in the case of indirect expropriation.

The second reason to think that indirect expropriation claims are especially prone to regulatory chill is mentioned earlier: because measures subsequently judged to be indirect expropriations most often bring the government no revenue, the threat of costly litigation may be a more effective deterrent than in the case of direct expropriation, where a government may simply tally the expected cost of arbitration against the current value of expropriation. By comparison, regulatory initiatives prone to indirect expropriation challenges would rarely succeed on cost-benefit grounds, given the high cost of litigation.

There is disagreement among scholars about the likelihood of the ISDS regime generating an effect of this sort, though the idea looms large in the public debate. Among legal scholars, some affirm that the investment regime "has serious potential to prevent the adoption of a regulatory measure with public purposes," 46 while others warn that "proof is very scarce," 47 though they go on to concede that it is more likely for developing countries.

There exists considerable anecdotal evidence of ISDS, or the threat of legal challenges, affecting government behavior in a way consistent with a regulatory chill hypothesis. When Canada attempted to enact tobacco legislation similar to the one that Australia implemented before being hit by a series of legal challenges, it faced threats of ISDS disputes from the tobacco industry on two occasions, in 1994 and 2001. In both cases, it ultimately backed down from the proposed law..$^{48}$

When Indonesia tried to ban open-pit mining in protected forests, mining companies threatened to launch investment disputes under the Aus-Indo and UK-Indo BIT. ${ }^{49}$ Indonesia backed down and exempted foreign mining investors from the proposed ban, even though legal observers noted that the threatened arbitration claims would have had little chance of succeeding. ${ }^{50}$ But the threat proved sufficiently compelling: as the Indonesian Environmental Minister admitted, "there were investment activities before the Forestry Act was effective. If shut down, investors demand compensation and Indonesia cannot pay." 51

In the Canadian and the Indonesian cases, the deterrent effect of the potential indirect expropriation claim was felt in the respondent country itself. But the same

45. See Philip Morris v. Australia, Philip Morris v. Uruguay, Vattenfall v. Germany, and Lone Pine v. Canada.

46. Chen $2015,63$.

47. de Mestral 2015, 16.

48. Lencucha, Labonte, and Drope 2015; and Tienhaara 2011.

49. Tienhaara 2011.

50. Gross 2003 performs a careful analysis of the likely claims that claimants might have brought against Indonesia — on indirect expropriation and fair and equitable treatment—and assesses their merits on the basis of analogous cases.

51. Ibid., 895 . 
effect can conceivably spill over across borders. New Zealand has long contemplated a plain-packaging tobacco law similar to the one that Australia implemented. When Australia's legislation was challenged in both trade and investment venues, New Zealand suddenly suspended the proposed legislation. ${ }^{52}$ Philip Morris praised New Zealand's decision as "demonstrat[ing] that the New Zealand government recognizes the significant international trade issues with standardized packaging and will not implement it until the pending international legal challenges to Australia's law are resolved." 53 Nor are these spillovers limited to New Zealand. In the case of tobacco, the countries most prone to deterrence, given their limited legal resources, are concentrated in Africa, where the tobacco industry's growth potential is highest. Namibia, Gabon, and Togo have faced ISDS threats in reaction to plans for tobacco regulation. As the World Health Organization's director general put it, existing legal challenges "are deliberately designed to instill fear in countries wishing to introduce similarly tough tobacco control measures." ${ }^{54}$ Namibia's proposed regulations were the most ambitious of the group, but in the face of threatened litigation, it has thus far come short of implementing any provisions from the proposed law. As the Namibian Health Ministry behind the legislation put it, "the fear is that they [the tobacco industry] have the money and they have the resources, so they can pay for anything." 55

Plain packaging stands out as an explicit example of firms relying on strategic ISDS litigation to deter regulation. Yet it also represents a most-likely case. Tobacco regulation is consistent across countries, increasing potential spillovers from litigation. The alleged indirect expropriatory act at issue brings the government no windfall, only foregone tax revenue. Many of the targeted states are developing countries. And the oligopolistic nature of the tobacco industry limits collective action problems that impede legal action. While challenges of indirect expropriation, or the mere threat of it, appear to have successfully swayed policy outcomes in a number of salient cases, the question is whether this represents a trend.

\section{Expectations Over Legal Success and Settlement}

To systematically test expectations, one would ideally observe all potential breaches of countries' investment obligations, and the merit of each, and see which ones are challenged. One could then examine whether investors require lower levels of legal merit to file indirect expropriation cases.

52. DG Trade 2014. Health Minister Tariana Turia stated, "the Government will wait and see what happens with Australia's legal cases.” (Philip Morris International 2013)

53. Ibid.

54. Margaret Chan, "The Changed Face of the Tobacco Industry," Keynote Address at the fifteenth World Conference on Tobacco or Health Singapore, 20 March 2012.

55. Sabrina Tavernise, "Tobacco Firms' Strategy Limits Poorer Nations' Smoking Laws," New York Times, 13 December 2013. 
But observing all measures open to challenge is not feasible; all we have are those cases that were challenged, raising potential issues of selection bias. Rather than trying to address the problem head-on by looking for a set of potential cases that were not challenged, one can think about the expected composition of the sample of observable claims, given that we know selection is occurring.

Expectations Over Legal Success. How are claims chosen? Investors deciding whether to bring a claim against a government perform a cost-benefit analysis. On the one hand, they weigh the expected benefit of a claim: the amount of expected compensation multiplied by the odds of success, to which they add any benefit derived from spillover effects, such as deterring regulation. On the other side of the scale, they consider the cost of litigation, which is constant across claim types. The resulting testable expectation is that if indirect expropriation claims, as a category, do give rise to a higher deterrence benefit, then the average legal merit of those claims that are filed should be lower, all else equal. Investors will require a lower level of legal merit to file a case if they think doing so also has a chance of staving off regulation. As a result, we should expect lower odds of a pro-claimant finding for those indirect expropriation claims that are filed.

The necessary assumption is that not all breaches-either over direct or indirect expropriation-are challenged. Actual selection must be taking place in both categories of claims for the reasoning to hold. Claimants must actually be weighing legal merit and deterrence benefits against costs of litigation, without one side of the scale dictating the filing decision. In the case of investment disputes, this seems a reasonable premise.

The expectation relies on "all else being equal," and thus it is worth verifying that the two claim types are comparable in other respects. If the size of the award, for instance, differs in one claim type over another, then it might be that investors fight one type of claim, even at lower levels of legal merit, simply because the financial value of success is greater. This does not appear to be the case: looking at the data on damages, we see that claims of indirect expropriation appear to be associated with slightly lower claimed damages on average, and slightly higher awards obtained; yet neither difference is statistically significant. The average amount claimed is USD \$1.6 billion for direct expropriation claims, and USD $\$ 1.1$ billion for indirect expropriation claims. These figures are skewed upward by two large outliers, but the difference remains insignificant if they are omitted. Similarly, there is no reason to think that litigation costs differ across the two categories. Direct and indirect expropriation claims are fought in much the same way, in the same arbitration venues. ${ }^{56}$ To sum up the expectation, if indirect expropriation claims carry additional deterrent benefits from the firm's standpoint, then conditional on being filed, they should be associated with lower odds of success. 
One response might be that some claims are simply harder to litigate than others, perhaps because they pose a harder legal test. That is, some types of claims would be inherently more meritorious. As a result, a difference in success rates could be reducible to a measure of legal complexity. Yet this belief also requires that claimants themselves be ignorant of such variation. Indeed, if some claims were harder to litigate than others, these differences should be internalized in investors' cost-benefit calculations when deciding whether to bring a case or not. That is, if one type of claim were "harder" to argue for any reason, investors should be less likely to bring it in the first place. By comparison, other investors with similar legal merit thresholds should be more likely to bring the "easier" case type, until the average difficulty of both cases would converge. Variation in the average "difficulty" of claims should thus not affect theoretical expectations unless we believe firms are unaware of it.

A related belief might be that even if the average legal merit of a pool of cases remained constant, greater uncertainty over this legal merit might itself affect the selection of cases, and thus the success rate of those claims that are filed. The rules covering indirect expropriation, as described earlier, are less established than those related to direct expropriation. Even if investors had similar beliefs about the average expected chance of success, they may be less confident in the accuracy of those odds when it comes to indirect expropriation.

Figure 2 illustrates a hypothetical distribution of beliefs about the legal merit of cases for two types of claims. Both types exhibit the same average expectation of success, but one (indicated by the dashed line) reflects greater uncertainty about the odds of success. If investors file a case any time it crosses a given merit threshold (indicated by the solid vertical line at $b$ ), then more uncertainty over outcomes leads

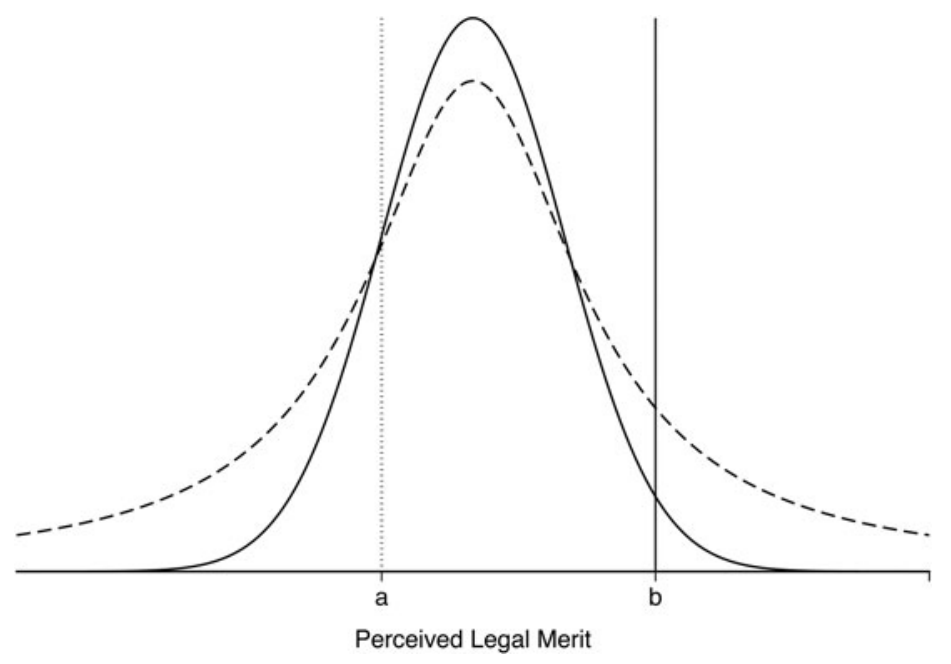

FIGURE 2. Effects of uncertainty of outcome on filing 
to a greater volume of cases, even as the average merit remains the same. Because the average merit is still the same, however, the pool of cases filed is necessarily weaker. As a result, conditional on being filed, cases taking on more ambiguous law would be less likely to succeed-owing strictly to a selection effect.

But this reasoning rests on some restrictive assumptions. First, most potential cases must not get filed: the required merit threshold must rest above the average merit of potential cases. If it is below (at the dotted vertical line at $a$ in Figure 2), then the effect of legal ambiguity would run in the opposite direction: ambiguity would be associated with fewer filings, and a higher average merit for these. The required threshold would remain constant for all types of claims, regardless of the level of uncertainty over their outcome. Yet it is likely that as uncertainty grows, investors will require higher perceived merit before filing. If risk aversion is sufficiently high, legal ambiguity could again be associated with a lower filing proportion. In other words, while there are plausible circumstances under which we might expect greater legal ambiguity, by itself, to result in a higher number of cases filed with lower merit, this effect is highly contingent.

What variation in uncertainty cannot explain is a trend through time: if anything, we would expect that ambiguity over indirect expropriation claims would decrease over time, as jurisprudence converges over its treatment of similar claims. This would decrease the proportion of indirect expropriation claims filed, and increase their average legal merit. But as I will show, the trend we observe is the opposite: the merit of claims decreases precipitously through time. This should lead us to think that uncertainty is unlikely to be playing a dominant role.

Expectations Over Settlement. Litigation is a costly and inefficient means of settling disagreements between parties. ${ }^{57}$ As Robert Hudec, one of the seminal theorists of the trade regime, put it, "no functioning legal system can wait until then [the ruling] to exert its primary impact." 58 The ISDS regime fares poorly by this metric: over two thirds of cases reach the award stage, with the remainder either settled or discontinued.

Which claims would we expect to settle early? If firms file indirect expropriation claims in part to deter governments' regulatory ambitions, then this has implications for the odds of early settlement: the deterrence objective is advanced by dragging out litigation as much as possible. In the Philip Morris v. Australia case, five years elapsed between the filing of the claim, which made headlines worldwide, and the arbitrators' decision on jurisdiction (in favor of Australia). It would have taken far more time if the arbitrators had reached a ruling on the merits. Of course, Philip Morris was aiming for a positive ruling, both to obtain the compensation it was seeking, and to set a favorable precedent. But even failing this, the firm benefited from any deterrent effect its litigation produced: in that case, New Zealand explicitly 
made it known that it would await the case's conclusion before continuing with its own plain-packaging regulation. ${ }^{59}$ The firm's willingness to drag out the case, in itself, may also have made subsequent threats to do the same against other countries more credible. Companies motivated in part by a deterrent effect should be less likely, all else equal, to settle early.

Governments' incentives across the two categories of cases combine to produce the same outcome, even if governments are aware of firms' incentives, and wary of the publicity associated with prolonged litigation. This is because of the prior expectation: if firms motivated in part by deterrence require a lower merit threshold to file, then governments will be faced with a pool of lower-merit cases. Governments should be, on average, less likely to settle these cases: they will expect higher odds of a favorable ruling during litigation, and will thus be less likely to give in early. Indeed, in both domestic and international legal systems, settlements in the "shadow of the law" usually represent a victory for the claimant. ${ }^{60}$ Looking at the data, we see that the amount of compensation obtained from settlements does not appear statistically different from the average amount awarded when the claimant wins the ruling. ${ }^{61}$ Applying this reasoning to our two claim types, we should expect indirect expropriation cases to be more likely to reach the ruling stage, and direct expropriation cases to be more likely to settle early.

\section{What Does the Record Show?}

It is useful to begin by visualizing a couple of different aspects of this question. First, Figure 3 illustrates the trend in legal success of indirect expropriation claims through time. The smoothed line shows the average annual success rate against a histogram showing the volume of concluded indirect expropriation cases. I purposefully align the cases shown in the histogram with those appearing on the legal merit curve. ${ }^{62}$ As a result, the volume of concluded cases shown decreases in more recent years, even as the number of indirect expropriation claims filed continues to increase: these more recent cases have yet to produce a ruling. The downwards trend through time is statistically significant in both linear and nonlinear estimations for every five-year span of the period under study. As the volume of litigation has increased, the rate of success of cases has declined precipitously.

Next, it is worth asking whether democracies are more prone to one type of claim than the other. If indirect expropriation claims are targeted at regulation, then we might expect that democracies would be more prone to such challenges. This is

59. Philip Morris International 2013.

60. Busch and Reinhardt 2000.

61. Average amount post-settlement is $\$ 495$ million (based on the thirty-one settlements with data on compensation amounts), compared to $\$ 524$ million following a ruling. These amounts are skewed upward by outliers, but the difference remains statistically insignificant without these.

62. The outcome recorded for a dispute in the histogram is shown in the same year, even if the ruling occurred later. 


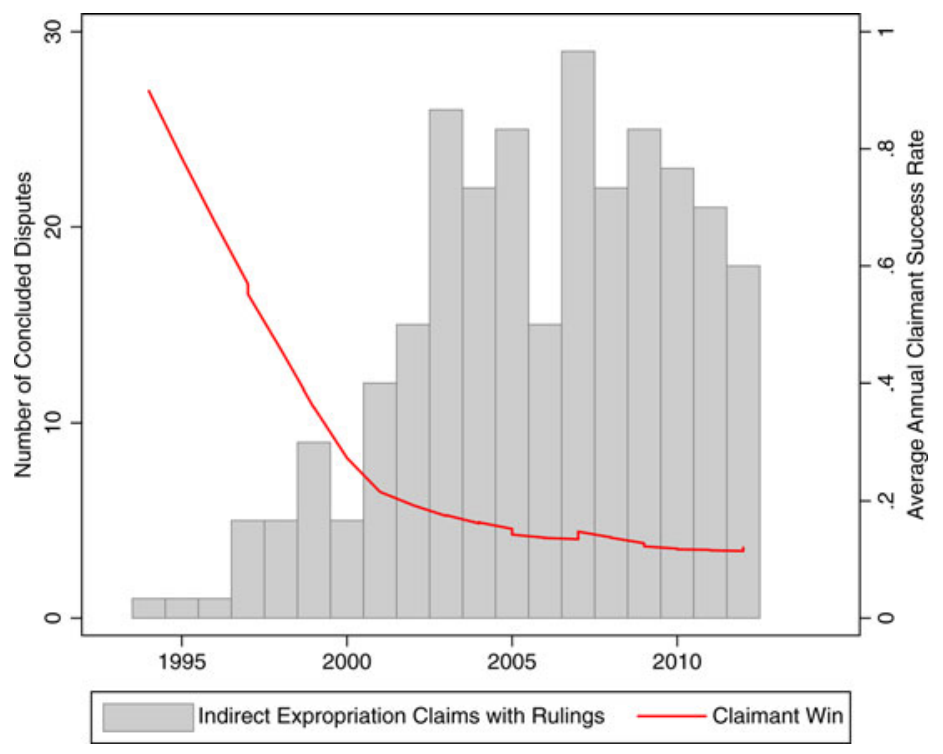

FIGURE 3. Direct $v$ s. indirect expropriation claims in ISDS

one recurrent criticism of ISDS in the policy debate. Figure 4 shows two pie charts. Democracies are defined as a Polity score of 7 or more, and nondemocracies are those countries with a Polity score of less than 5 . The difference is readily apparent: democracies face mostly indirect expropriation claims, while these constitute a minority of the claims brought against nondemocracies. The opposite pattern pertains to direct expropriation claims, which make up nearly twice the proportion of litigation against nondemocracies as they do against democracies. One can quickly verify whether the rate of success differs by regime. Looking specifically at indirect expropriation, we see that democracies appear to lose 62 percent fewer indirect expropriation cases. ${ }^{63}$

In studies of ISDS, much attention has been paid to the claimant's industry. ${ }^{64}$ For this reason, it is useful to look at variation in the rate of success of claims across different sectors. Figure 5 relies on the ISIC classification of the industry at issue in the dispute to chart the success rate across all industrial sectors that have seen a minimum of ten legal claims filed from 1993 to 2015. I also include the rate of settlement for comparison. While there is visible variation across industries, no obvious pattern emerges: using Wellhausen's or Hafner-Burton and colleagues' coding, neither mobile industries nor capital-intensive ones are consistently associated with greater

63. These descriptive statistics do not control for wealth, which plays an important confounding role. 64. Wellhausen 2016 distinguishes industries by degree of "mobility"; Hafner-Burton, SteinertThrelkeld, and Victor 2014 distinguish by capital intensity. 
or lower rates of legal success or settlement. ${ }^{65}$ Yet the variation across sectors is nonetheless sufficient to explicitly take it into account in the analyses that follow.
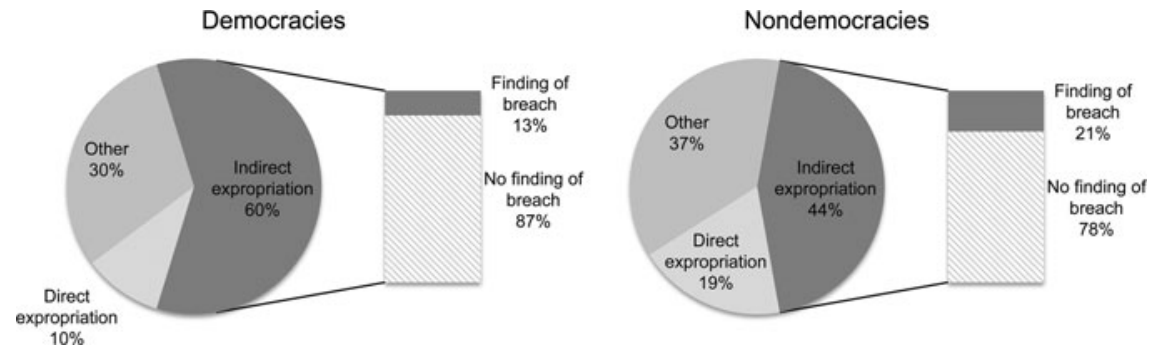

FIGURE 4. Legal claims and success rate by regime type

The mention of settlement brings us to the next important point. One of my theoretical expectations is that if indirect expropriation claims have a deterrent function for firms, then they should be less likely to settle, and more likely to produce a ruling. The expectation over settlement also gains from being tested before the analysis of legal merit, since it gets at a type of selection that bears on that analysis: which claims are more likely to be settled will affect the pool of cases that make it to a ruling. Once again, a simple descriptive test allows us to provisionally reject the null hypothesis that settlement rates are the same across our two claim types of interest: the average rate of settlement for direct expropriation claims is 31 percent, versus 12 percent for indirect expropriation claims, which are far more likely to go on to a ruling. This concords with theoretical expectations over deterrence, and just as importantly, it dictates the type of estimation required for our main legal merit test. Any estimation of legal merit needs to account for the fact that a greater proportion of indirect expropriation claims are selected into the ruling stage.

To do so, I rely on a Heckman probit selection estimation. This model allows me to first estimate the odds of a case reaching the ruling, and then to use those estimates to correct for selection in the outcome equation, which estimates the odds of a ruling in one direction or the other. To identify the model, one ideally needs a variable that affects the odds of a ruling, but that does not have an independent impact on the second-stage outcome, the direction of the ruling. Theory provides us with a good candidate: a growing number of studies, looking especially at litigation in the trade regime, document how privacy increases the odds of settlement. ${ }^{66}$ Specifically, settlement grows more likely when the stakes of a case can remain private. This insight can be readily applied here. One of the main dimensions of privacy in ISDS is whether the amount of compensation sought by the claimant is publicized. 
Publicly displaying the "ask" during bargaining renders agreement less likely—that is why interstate negotiations are invariably held in private. Yet whether the amount of compensation sought is made public or not is unlikely to have an independent bearing on the direction of the ruling. Indeed, when it is included in the second stage in the analysis, it is insignificantly related to the ruling direction. I code this first-stage variable, AMOUNT SOUGHT PRIVATE, by looking at whether UNCTAD is able to arrive at this number.

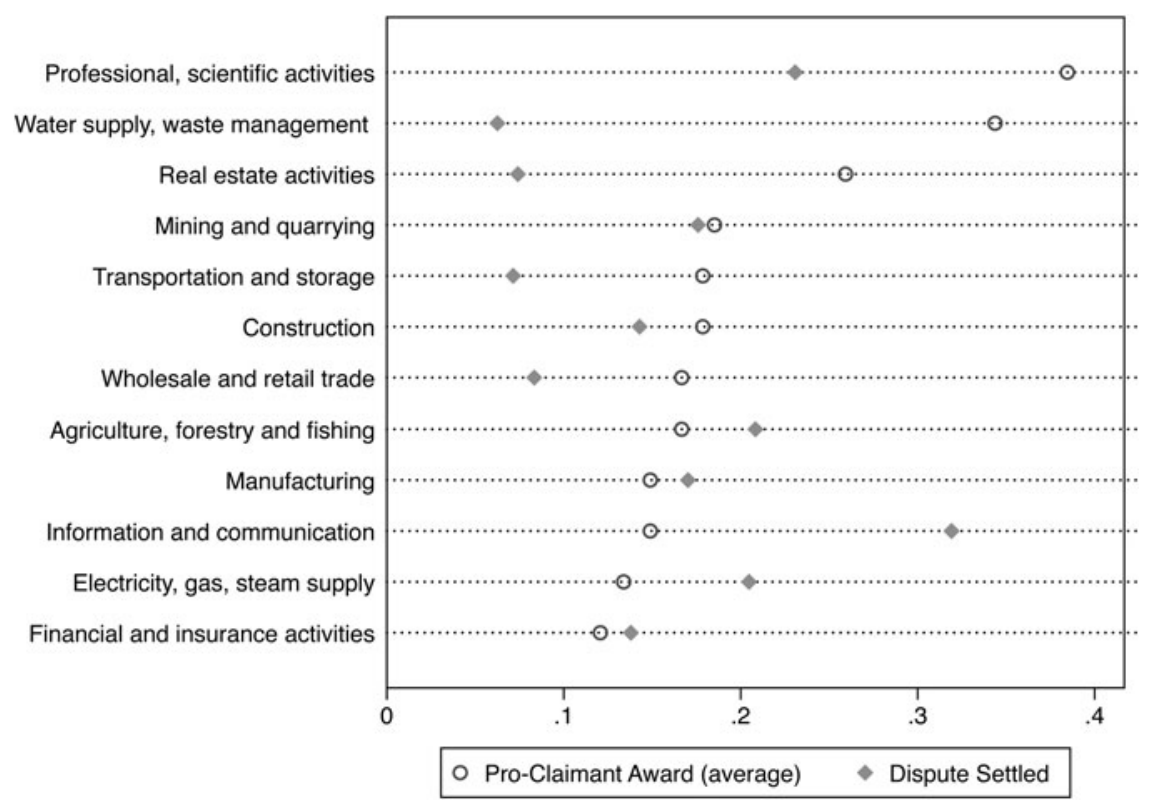

FIGURE 5. Rates of success across industrial sectors

The main explanatory variable of interest is INDIRECT EXPROPRIATION CLAIM, coded in contradistinction to direct expropriation claims. So that these refer to a common baseline, I code a variable, OTHER LEGAL CLAIM, to refer to cases that contain neither direct nor indirect expropriation claims. ${ }^{67}$ I expect indirect expropriation claims to show higher odds of ruling, but lower odds of success for the claimant, conditional on a ruling. Finally, I include a measure of the firm's prior experience with arbitration, which may shape preferences over the value of settlement.

In the second stage, the outcome variable is the direction of the tribunal ruling. Here I rely on UNCTAD's own coding, which distinguishes between awards "decided in favor of the investor" and awards "decided in favor of the State." I

67. Estimations that simply include an Indirect/Direct Expropriation indicator show the same results: see the appendix. 
include only those disputes that have reached a known outcome, which leaves me with 375 concluded cases. ${ }^{68}$ I also control for a number of potentially confounding variables that might affect the direction of the award. First among these is wealth, since poorer countries may lack the legal capacity to mount an effective defense against investment challenges. I use the log of GDP per capita, in constant 2005 dollars, obtained from the World Development Indicators. Along these lines, COUNTRY LEGAL EXPERIENCE controls for the number of ISDS challenges a country has handled in the past, to account for any learning effect, which has been identified in dispute settlement in the trade regime. ${ }^{69}$ Because there is a prevalent belief that filing more claims in a case is a sign of low legal merit, CLAIMS NUMBER controls for the number of legal claims filed. The average is two claims, but some disputes include up to seven. I include a variable for DEMOCRACY, given the pattern described in Figure 4. I also account for the investment agreement underlying the dispute by including a dummy variable for the two agreements most frequently invoked, NAFTA and the ENERGY CHARTER, in case either of these sees higher odds of awards in a given direction. One-fifth of disputes fall under one of these two agreements. Finally, I control for time, which I have already shown to be an important factor. We know that the legal success of claims has been decreasing over the past two decades. The question is whether there is a difference in the success rate of different claims once we control for this catholic trend. I include Schoenberg splines at four knots in all estimations; using a simple year term instead produces the same results. Because there may be some commonality of outcome within the industry of the claimant, as per Figure 5, I cluster the robust standard errors on the ISIC sector of the relevant investment.

Table 1 shows the results. The first column estimates the odds of the firm winning the case, while the second column estimates the odds of the state winning-as the results demonstrate, these are not exact opposites: cases can also be discontinued, or decided in favor of neither party.

Indirect expropriation claims are significantly less likely to result in pro-claimant findings. When a case rests on an indirect expropriation claim, the odds of the claimant winning immediately drop by 52 percent, keeping all other variables at their mean values. In other words, indirect expropriation claims fare significantly worse, all else equal. This is consistent with the belief that investors may derive some additional benefit from filing these cases that leads them to countenance lower levels of legal merit.

Across all estimations, richer countries fare better: the state wins more often, the wealthier it is. Controlling for wealth, democracy appears to have a tenuous negative effect on the odds of a state successfully warding off a legal challenge. This relationship between wealth and success is robust across both pro-firm and pro-state awards,

68. Tellingly, there are 257 currently pending cases across the investment regime. Of the 375 sample cases, I exclude nine cases that feature both direct and indirect expropriation claims. These are included in the appendix estimations.

69. Davis and Bermeo 2009. 
and directly contradicts recent claims by Franck, based on smaller samples. ${ }^{70}$ A country's legal experience with arbitration is not associated with higher odds of success and actually shows a weak negative relationship. This is likely a result, at least in part, of flurries of challenges against the same state arising from a similar context. For instance, Spain has recently been hit by over twenty disputes following the suspension of renewable energy projects in the midst of its recent fiscal crisis. When this happens, any learning effect is limited, and the state may face a cluster of losses, as Argentina did after its own crisis.

TABLE 1. Legal merit in the investment regime

\begin{tabular}{|c|c|c|}
\hline & $\begin{array}{c}\text { (1) } \\
\text { Pro-firm ruling }\end{array}$ & $\begin{array}{c}\text { (2) } \\
\text { Pro-state ruling }\end{array}$ \\
\hline INDIRECT EXPROPRIATION CLAIM & $\begin{array}{l}-0.92 * * * \\
(0.22)\end{array}$ & $\begin{array}{l}0.92 * * * \\
(0.27)\end{array}$ \\
\hline OTHER LEGAL CLAIM & $\begin{array}{c}-0.59 * * \\
(0.28)\end{array}$ & $\begin{array}{c}0.51 \\
(0.34)\end{array}$ \\
\hline GDP/CAP (LOG) & $\begin{array}{l}-0.31 * * * \\
(0.05)\end{array}$ & $\begin{array}{l}0.33 * * * \\
(0.05)\end{array}$ \\
\hline COUNTRY LEGAL EXPERIENCE & $\begin{array}{l}0.02 * * \\
(0.01)\end{array}$ & $\begin{array}{r}-0.02 * \\
(0.01)\end{array}$ \\
\hline NAFTA & $\begin{array}{c}-0.10 \\
(0.16)\end{array}$ & $\begin{array}{c}0.20 \\
(0.24)\end{array}$ \\
\hline ENERGY CHARTER & $\begin{array}{c}0.02 \\
(0.20)\end{array}$ & $\begin{array}{c}-0.09 \\
(0.27)\end{array}$ \\
\hline CLAIMS NUMBER & $\begin{array}{c}0.01 \\
(0.04)\end{array}$ & $\begin{array}{c}-0.01 \\
(0.04)\end{array}$ \\
\hline REGIME TYPE & $\begin{array}{l}0.03 * * \\
(0.01)\end{array}$ & $\begin{array}{l}-0.03 * * \\
(0.01)\end{array}$ \\
\hline Constant & $\begin{array}{c}-21.59 \\
(13.74)\end{array}$ & $\begin{array}{c}33.00 * \\
(19.94)\end{array}$ \\
\hline GOES TO RULING & & \\
\hline AMOUNT SOUGHT PRIVATE & $\begin{array}{l}-0.55^{* * * *} \\
(0.11)\end{array}$ & $\begin{array}{l}-0.59 * * * \\
(0.14)\end{array}$ \\
\hline INDIRECT EXPROPRIATION CLAIM & $\begin{array}{l}0.57 * * * \\
(0.17)\end{array}$ & $\begin{array}{l}0.56 * * * \\
(0.18)\end{array}$ \\
\hline OTHER LEGAL CLAIM & $\begin{array}{c}0.26 \\
(0.20)\end{array}$ & $\begin{array}{c}0.24 \\
(0.22)\end{array}$ \\
\hline INVESTOR LEGAL EXPERIENCE & $\begin{array}{c}0.00 \\
(0.02)\end{array}$ & $\begin{array}{c}0.03 \\
(0.09)\end{array}$ \\
\hline Constant & $\begin{array}{l}0.46^{* * * *} \\
(0.15)\end{array}$ & $\begin{array}{l}0.46 * * * \\
(0.13)\end{array}$ \\
\hline $\begin{array}{l}\text { Time cubic splines } \\
N\end{array}$ & $\begin{array}{l}\text { Yes } \\
363\end{array}$ & $\begin{array}{l}\text { Yes } \\
363\end{array}$ \\
\hline
\end{tabular}

Notes: Heckman probit selection model with maximum likelihood (ML) estimates. The first stage estimates likelihood of an award being rendered. The second stage estimates likelihood of a pro-claimant award (column 1) and a pro-state award (column 2). Robust standard errors clustered on the ISIC sector. $* p<.10 ; * * p<.05$; *** $p<.01$.

The selection model performs well: the Wald test for the first model shows a $\chi^{2}$ of 8.15 , suggesting that the null according to which the two equations are unrelated can 
be rejected-accounting for selection is called for. Just as important, the key variable identifying the selection model behaves as expected: when the amount of compensation sought is made private, the odds of settlement are significantly increased. In fact, the odds of a ruling being produced increase by half when the amount sought by the claimant is kept private.

Table 1 thus provides support for the two major theoretical expectations: (1) indirect expropriation claims are more likely to drag on and lead to a ruling, and (2) conditional on proceeding to a ruling, investors are significantly more likely to lose.

The results appear highly robust. Including country wealth or experience at the first stage does not affect the findings for claim type at either stage. Controlling for all disputes filed by individuals at both stages only strengthens the findings for indirect expropriation claims. There is some anecdotal evidence that fair-and-equitable-treatment (FET) claims are included in the event that indirect expropriation claims fail. Might it be that those disputes that include both types of claim do better, winning at least one of the two claims? I account for this possibility by replacing the claim type by an indicator variable for disputes that include both indirect expropriation and fair-and-equitable-treatment claims. The results remain the same for both settlement and ruling outcomes.

Finally, while the Heckman selection model is called for on theoretical grounds and supported by model diagnostics, a single-stage probit model produces the same findings, both when the second-stage equation is run by itself, and when all the first-stage variables are added to the right-hand side. In all cases, indirect expropriation cases are more likely to be ruled in favor of the state, and less likely to be ruled in favor of firms.

\section{Conclusion}

The investment regime has become the most controversial aspect of global governance. Here, I assess the extent to which this controversy is warranted. I argue that the regime has indeed undergone a fundamental shift since its origins, though it is largely of a de facto rather than de jure nature. The long "dormant" issue of indirect expropriation has been permanently stirred up. ${ }^{71}$ The investor-state arbitration regime now considers mostly claims of indirect expropriation, rather than the type of "sovereign theft" represented by direct takings and often envisioned by the literature. And it increasingly targets democracies, rather than rent-seeking regimes with poor rule of law. These are changes that the IPE literature studying investment has yet to fully come to terms with. Much of our theoretical apparatus is suited to a definition of expropriation that is out of sync with the reality of the regime.

Yet the paper's main findings are more nuanced. In trying to defend the legitimacy of the investor-state regime, policy-makers often point out that investors fail to win 
most of the claims they bring. ${ }^{72}$ I suggest that this is precisely where the problem may lie. An international legal regime where litigation is both costly and generally unsuccessful fails at its primary function of bringing attention to treaty violations by sovereign states. The incentives it generates may be skewed if claimants gain even when they bring weak cases. If the regime no longer identifies actual rent seeking by governments, its informational function is jeopardized.

Because indirect expropriation most often targets regulation, investors filing these claims may derive a benefit from litigation no matter whether they win if they are able to sway policy. I document a set of cases where the threat of costly litigation alone appears to have been enough to temper regulatory ambitions in a countryin Canada, New Zealand, Indonesia, and Namibia. If a set of claims carries benefits other than financial compensation, then the process of case selection should lead us to expect that conditional on being filed, these cases should display lower legal success, all else equal. The evidence appears consistent with these beliefs.

In aggregate, the legal success of cases has declined precipitously over time, and this decline is concentrated in indirect expropriation claims. Investors have won only 21 percent of indirect expropriation disputes in the last decade. These are more apt to generate positive spillovers for the investor by deterring regulation, and they are systematically less successful than other types of claims, such as direct expropriation cases. Finally, indirect expropriation claims are 26 percent more likely to persist to the ruling stage, in a manner consistent with the belief that investors who bring such cases may be more interested in the benefits of litigation itself than in securing a favorable early settlement. By comparison, direct expropriation claims are far more likely to settle.

These findings speak to the low odds of success of indirect expropriation claims; they are not a normative statement about their desirability. After all, human rights and civil rights lawyers routinely file suits they know to have little chance of success. This is because beyond winning the case, they want to bring attention to an issue of public interest, or set an important precedent. ${ }^{73} \mathrm{We}$ expect low-probability cases when litigants can countenance a low-merit threshold because they have objectives beyond the case at hand. The assessment of social welfare consequences then follows not from the probability of success per se, but from the broader objective being pursued. In the case of civil rights litigation, that objective may be to bring public attention to a developing rights issue. In the case of investor-state disputes, one possible objective may be to temper governments' regulatory ambitions.

States are catching on to the trends I have outlined. In fact, governments' attempts to revise existing agreements and amend the design of new agreements suggest the extent to which these changes were unanticipated. Miscalculation in international relations is rare; sustained miscalculation, repeated across hundreds of agreements, 
is rarer still. Yet all signs point to governments having failed to foresee the development arc of ISDS.

The US, arguably the world's greatest proponent of investment rules, has revised its model BIT in reaction to its NAFTA experience. Legal scholars point out that this change was precisely in reaction to the way in which "several [chapter 11 claims were] perceived as 'frivolous' by the American government." 74 The EU, whose member states, after all, invented the practice of ISDS, has also adapted its position and sought to decrease the risk of litigation challenging public interest regulation. ${ }^{75}$ Its agreement with Canada, CETA, contains a provision allowing states to "file an objection that a claim is manifestly without legal merit," and for the first time seeks to narrowly define indirect expropriation. ${ }^{76}$ The TPP similarly tries to tilt control towards governments. It remains that none of these novel agreements have been ratified at the time of writing precisely because of the public mistrust surrounding ISDS. The question is thus whether these reforms are coming too late to be implemented.

\section{Supplementary Material}

Supplementary material for this research note is available at $<$ https://doi.org/10.1017/ S0020818317000212>.

\section{References}

Allee, Todd, and Clint Peinhardt. 2011. Contingent Credibility: The Impact of Investment Treaty Violations on Foreign Direct Investment. International Organization 65 (3):401-32.

Bown, Chad P. 2005. Participation in WTO Dispute Settlement: Complainants, Interested Parties, and Free Riders. World Bank Economic Review 19 (2):287-310.

Brutger, Ryan. 2014. Screening for Success: The Effect of Firm Signaling on WTO Case Selection. Working Paper, Princeton University, Princeton, NJ.

Busch, Marc L., and Eric Reinhardt. 2000. Bargaining in the Shadow of the Law: Early Settlement in GATT/WTO Disputes. Fordham International Law Journal 24 (1):158-72.

. 2006. Three's a Crowd: Third Parties and WTO Dispute Settlement. World Politics 58 (3):446-77.

Busch, Marc L., Eric Reinhardt, and Gregory Shaffer. 2009. Does Legal Capacity Matter? A Survey of WTO Members. World Trade Review 8 (4):559-77.

Chen, Tsai-Fang. 2015. Deterring Frivolous Challenges in Investor-State Dispute Settlement. Contemporary Asia Arbitration Journal 8 (1):61-80.

Cole, Harold L., and William B. English. 1991. Expropriation and Direct Investment. Journal of International Economics 30 (3):201-27. 
Commission, Jeffrey P. 2016. How Much Does an ICSID Arbitration Cost? A Snapshot of the Last Five Years. Kluwer Arbitration Blog. Available at <http://kluwerarbitrationblog.com/2016/02/29/how-muchdoes-an-icsid-arbitration-cost-a-snapshot-of-the-last-five-years/>. Accessed 3 February 2017.

Davey, William J., and Amelia Porges. 1998. Comments on Performance of the System I: Consultations and Deterrence. International Lawyer 32 (3):695-707.

Davis, Christina L., and Sarah Blodgett Bermeo. 2009. Who Files? Developing Country Participation in GATT/WTO Adjudication. The Journal of Politics 71 (3):1033-49.

de Mestral, Armand. 2015. Investor-State Arbitration Between Developed Democratic Countries. Centre for International Governance Innovation Paper Series No. 1.

DG Trade. 2014. Public Consultation on Modalities for Investment Protection and ISDS in TTIP. Available at <http://trade.ec.europa.eu/doclib/docs/2014/march/tradoc_152280.pdf>. Accessed 15 July 2016.

Dolzer, Rudolf. 2005. Fair and Equitable Treatment: A Key Standard in Investment Treaties. The International Lawyer 39 (1):87-106.

Escarcena, Sebastián López. 2014. Indirect Expropriation in International Law. Cheltenham, UK: Edward Elgar.

European Commission. 2013. Incorrect Claims About Investor-State Dispute Settlement. Available at <http://trade.ec.europa.eu/doclib/docs/2013/october/tradoc_151790.pdf>. Accessed 3 February 2017.

Fortier, L. Yves, and Stephen L. Drymer. 2004. Indirect Expropriation in the Law of International Investment: I Know It When I See It, or Caveat Investor. ICSID Review 19 (2):293-27.

Franck, Susan D. 2015. Conflating Politics and Development: Examining Investment Treaty Arbitration Outcomes. Virginia Journal of International Law 55 (1):13-71.

Gagné, Gilbert, and Jean-Frédéric Morin. 2006. The Evolving American Policy on Investment Protection: Evidence From Recent FTAs and the 2004 Model BIT. Journal of International Economic Law 9 (2): 357-82.

Gibson, Christopher S. 2015. Yukos Universal Limited (Isle of Man) v. The Russian Federation: A Classic Case of Indirect Expropriation. ICSID Review 30 (2):303-14.

Gilligan, Michael, Leslie Johns, and Peter B. Rosendorff. 2010. Strengthening International Courts and the Early Settlement of Disputes. Journal of Conflict Resolution 54 (1):5-38.

Gross, Stuart G. 2003. Inordinate Chill: BITS, Non-NAFTA MITS, and Host-State Regulatory FreedomAn Indonesian Case Study. Michigan Journal of International Law 24 (3):893-960.

Hafner-Burton, Emilie, Zachary Steinert-Threlkeld, and David G. Victor. 2014. Transparency of InvestorState Arbitration. Social Science Research Network. Available at <https://ssrn.com/abstract=2431522>. Accessed 3 February 2017.

Hudec, Robert E. 1993. Enforcing International Trade Law: The Evolution of the Modern GATT Legal System. Salem, NH: Butterworth Legal Publishers.

Jensen, Nathan M., Noel P. Johnston, Chia-yi Lee, and Abdulhadi Sahin. 2012. Economic Shock, Political Shifts, and Sovereign Theft: The Domestic and International Determinants of Investment Expropriation. Working Paper.

Johns, Leslie, and Krzysztof J. Pelc. 2014. Who Gets to Be in the Room? Manipulating Participation in WTO Disputes. International Organization 68 (3):663-99.

2016. Free-Riding on Enforcement in the WTO Social Science Research Network. Available at <https://ssrn.com/abstract=2782560>. Accessed 3 February 2017.

Kucik, Jeffrey, and Krzysztof J. Pelc. 2016a. Do International Rulings have Spillover Effects? The View from Financial Markets. World Politics 68 (4):713-51.

2016b. Measuring the Cost of Privacy: A Look at the Distributional Effects of Private Bargaining. British Journal of Political Science 46 (4):861-89.

Lazer, David. 2001. Regulatory Interdependence and International Governance. Journal of European Public Policy 8 (3):474-92.

Lencucha, Raphael, Ronald Labonte, and Jeffrey Drope. 2015. Tobacco Plain Packaging: Too Hot for Regulatory Chill. The Lancet 385 (9979):1723-24.

Li, Quan, and Adam Resnick. 2003. Reversal of Fortunes: Democratic Institutions and Foreign Direct Investment Inflows to Developing Countries. International Organization 57 (1):175-211. 
Mansfield, Edward D., Helen V. Milner, and Peter B. Rosendorff. 2002. Why Democracies Cooperate More: Electoral Control and International Trade Agreements. International Organization 56 (3):477513.

Pauwelyn, Joost. 2014. At the Edge of Chaos? Foreign Investment Law as a Complex Adaptive System, How It Emerged and How It Can Be Reformed. ICSID Review 29 (2):372-418.

- 2015. WTO Panelists Are from Mars, ICSID Arbitrators Are from Venus: Why? And Does It Matter? Working Paper. Available at <http://www.iilj.org/wp-content/uploads/2016/09/PaulwelynIILJ Colloq2015.pdf>. Accessed 3 February 2017.

Pelc, Krzysztof J. 2014. The Politics of Precedent in International Law: A Social Network Application. American Political Science Review 108 (3):547-64.

Pelc, Krzysztof J., and Johannes Urpelainen. 2015. When Do International Economic Agreements Allow Countries to Pay to Breach? The Review of International Organizations 10 (2):231-64.

Philip Morris International. 2013. Philip Morris International Comments on New Zealand's Standardized Packaging Announcement. Available at <https://www.pmi.com/investor-relations/press-releases-andevents/press-releases-overview/press-release-details/?newsId=1786037>. Accessed 17 May 2017.

Post, Diahanna L. 2005. Standards and Regulatory Capitalism: The Diffusion of Food Safety Standards in Developing Countries. The Annals of the American Academy of Political and Social Science 598 (1): 168-83.

Reynolds, Susan. 2010. Before Eminent Domain: Toward a History of Expropriation of Land for the Common Good. Chapel Hill, NC: University of North Carolina Press.

Schultz, Thomas, and Cédric Dupont. 2014. Investment Arbitration: Promoting the Rule of Law or Overempowering Investors? A Quantitative Empirical Study. European Journal of International Law 25 (4): 1147-68.

Simmons, Beth A. 2014. Bargaining over BITs, Arbitrating Awards: The Regime for Protection and Promotion of International Investment. World Politics 66 (1):12-46.

Simmons, Beth A., and Zachary Elkins. 2004. The Globalization of Liberalization: Policy Diffusion in the International Political Economy. American Political Science Review 98 (1):171-89.

Tienhaara, Kyla. 2011. Regulatory Chill and the Threat of Arbitration: A View from Political Science. In Evolution in International Treaty Law and Arbitration, edited by Chester Brown and Kate Miles, 606-28. New York: Cambridge University Press.

Tomz, Michael, and Mark L.J. Wright. 2010. Sovereign Theft: Theory and Evidence about Sovereign Default and Expropriation. In The Natural Resources Trap: Private Investment Without Public Commitment, edited by William Hogan and Federico Sturzenegger, 69-110. Cambridge, MA: MIT Press.

UNCTAD. 2010. Investor-State Disputes: Prevention and Alternatives to Arbitration. UNCTAD Series on International Policies for Development, 16. Available at <http://unctad.org/en/docs/diaeia200911_en. pdf>. Accessed 17 May 2017.

- 2016. Investment Dispute Settlement Navigator. Available at <http://investmentpolicyhub.unctad. org/ISDS > . Last accessed 17 May 2017.

Wellhausen, Rachel. 2016. Recent Trends in Investor-State Dispute Settlement. Journal of International Dispute Settlement 7 (1):117-35. 
Reproduced with permission of copyright owner. Further reproduction prohibited without permission. 